\title{
Analysis of Economic Development Impact of Remittances on Recipient (Zimbabwe) and Remitting (South Africa) Countries
}

\author{
George Chirwa, Abdulla Kader \\ Department of Leadership, University of Kwazulu Natal, Durban, South Africa \\ Email address: \\ george@africawide.co.za (G. Chirwa), AbdullaK@Nedbank.co.za (A. Kader)
}

To cite this article:

George Chirwa, Abdulla Kader. Analysis of Economic Development Impact of Remittances on Recipient (Zimbabwe) and Remitting (South Africa) Countries. Journal of Business and Economic Development. Vol. 3, No. 3, 2018, pp. 77-85. doi: 10.11648/j.jbed.20180303.13

Received: August 20, 2018; Accepted: October 29, 2018; Published: November 21, 2018

\begin{abstract}
The importance of remittances to recipient economies has been greatly researched and there is a general consensus around their continued significance to these countries. However, their impact on the development of the receiving economies remains a subject of much debate among academics and policy makers. There is even greater dearth of academic research and debate around the impact of remittances on the sending economies. Unlike Foreign Direct Investment (FDI) flows, whose impact on the economies can be closely correlated to the economies' outputs, remittances are micro-payments fragmented to multiple recipients, from multiple individual senders with different motives and for a multitude of uses. The researcher modified The Newtonian Gravity model first adapted by a Dutch economist, Timbergen as the first published proponent of the Newtonian gravity model application in analysis of financial flows. The model was applied to remittance flows between the sender and recipient countries, and assess the economic impact on the two economies. The key corridor of the research was between Zimbabwe and South Africa, which represents one of the biggest regional remittances flow corridors in Africa. The investigation revealed that remittances not only had a significant impact on recipient economies, but showed a negative correlation with Zimbabwe's GDP in particular. Outflows of remittances proved to have very little impact on the sending country, South Africa. On further examination of the other countries studied, distance from the main remitting country had a negative correlation with remittances flows. Economic impairment of receiving countries increased their dependency on the remittances flows, and the funds were not directed at activities that directly contributed to GDP growth of recipient countries.
\end{abstract}

Keywords: Remittances, Economic Development, Gravity Model

\section{Introduction}

Giuliano and Ruiz-Arranz [14] argued that despite the increasing importance of remittances in total international capital flows, the relationship between remittances and growth has not been adequately studied. Their macroeconomic impacts are not well understood beyond the fact that remittances alleviate poverty [2]. Barajas et al.[2] further argue that remittances have minimal impact on longterm growth because they are mostly used for consumption. Giuliano and Ruiz-Arranz [14] state that the relationship between remittances, financial development and growth is a priori ambiguous in that, in well-functioning financial markets, lowering costs of conducting transactions may help direct remittances to projects that yield highest returns and therefore enhance growth rates of recipient communities. They also argued that markets with well-developed payment systems, with lower costs of remitting and fewer policy barriers tended to attract more remittances. However, their developmental impact was not amplified. As a result, these assertions have very different bearings on the decisions and strategies for policy makers.

According to the World Bank [30], Zimbabwe, along with several other developing countries, does not report remittance inflows data to the IMF. In 2015, remittances out of South Africa into the SADC region reached an estimated total of R11.1bn ( $\$ 1.2$ bn) per annum [11], with Zimbabwe as the top destination of these remittances, accounting for $60 \%$. 
DNA analysis and other various sources [11] claim that Zimbabwean migrants also constitute the bulk (68\%) of the total estimated migrants in South Africa.

Zimbabwe is also one of South Africa's biggest African trade partners, with a reported total share of $11 \%$ of South Africa's African trade [24] estimated to \$2.86bn in 2012. On the other hand, South Africa is Zimbabwe's biggest trade partner; accounting for $24 \%$ of its country's trade in 2011 [9]. The full impact of the resultant remittances on the economic development of both countries has not been fully studied despite these important economic and cultural ties between the two countries.

Zimbabwe is a country with a long history of migration, for over a century it served as both a sending and receiving country within the Southern African region [19]. However, the recent economic and political instabilities have altered this with sending migration becoming the norm [4]. This was dubbed the "Zimbabwean exodus", with South Africa being one of the favoured destinations.

There are several push factors, such as the economic down turn, wide spread unemployment, high poverty levels, political instability, reported human rights abuses and declining literacy rates. Other strong pull factors fueling the migrations include:

(1) a better economy in South Africa;

(2) more job opportunities, higher standards of living;

(3) a more robust democracy; and

(4) geographical proximity.

South Africa and Zimbabwe are neighbouring partners that share a long historical, economic and cultural relationship. Deep cultural links can be traced back to the mass migration during the Mfecane period (1820 -1830s) which was a key cultural shape shifter when tribal wars, famine and ecological factors in South Africa caused huge displacements of communities that reverberated across Southern Africa. This resulted in displaced communities from South Africa settling into what today are neighbouring countries. In present day Zimbabwe, the Ndebele people who settled in the southwestern province can be traced back to the Zulu nation, originating in present day KwaZulu Natal, South Africa. Over the years, there has been a continuous migration of labourers between the two countries, with Zimbabweans being attracted to the more developed South African economy driven by opportunities in areas such as mining and construction. The most recent upsurge in this movement has been attributed to the 2008 Zimbabwe economic meltdown that resulted in an estimated 2 million people crossing into South Africa [11].

There have been a few recent studies that looked at the positive impact of remittances between South Africa and Zimbabwe on remitters' communities [9, 25, 3]. De Haas [5] acknowledged the developmental impact, but cautioned on the 'remittance euphoria' (positive impact on the country of origin), as an exaggeration. The prevalence of an unattractive investment environment, restrictive immigration policies and interrupted circular migration prevents the high development potential of remittances from being fully realised.

Consequently, this study seeks to add to this academically limited body of knowledge by obtaining an understanding of the remittances impact on the migrants' country of origin, as well as their adopted community. Furthermore, there is limited data and literature on the developmental impact of remittances on the remitting country as the focus has always been on the less-developed recipient country. The perceived impact of remittances on the receiving country tends to be bigger than on the more developed remitting country. Barajas, et al. [2] observed that on a country-by-country basis, workers' remittances exceeded 1\% of GDP (on average) in over 60 developing countries. Seven of these countries had average workers' remittances-GDP ratios of $15 \%$ or higher.

Besides sharing a geographical border, Zimbabwe and South Africa also have a symbiotic relationship. South Africa is Zimbabwe's largest trade partner, with net flows into Zimbabwe. Zimbabwean migrants are the largest grouping of migrants from Africa [11], with the highest remittance flows from South Africa. It is in South Africa's best interest to have a prospering, robust Zimbabwean economy as any negative shocks will affect it directly, through decreased trade or indirectly, through a refugees surge for example.

This study also seeks to fill in the void in academic literature, on the link between remittances and its impact on the societal and economic development of the migrants' country of origin and residing country, with the focus on Zimbabwe and South Africa respectively

\section{Objectives of the Study}

The objectives of this study were:

(1) What is the impact of remittances on the economy and society of the recipient country?

(2) What is the impact of remittances on the economy and society of the remitting country?

\section{Research Methodology}

There is a general dearth of academic literature on the true impact of remittances on the receiving country, and greater deficiency of material on the impact on the sending country. The macroeconomic impact on the migrant host economy is even less, as focus has been at microeconomic level [1]. Empirical literature by Dustmann and Mestres [7] has shown that in contrast to cyclical migration, migrants' planned duration of stay and intended settlement, has a huge impact on the volumes of remittances, which in turn impact the hosting economy as a whole. Temporary migrants generally tend to work more and remit more especially in the first years, and spend less in the host country. Another study by Olney (2014) found that increases in remittances led to depression of wages of native workers in the host country.

Baas and Melzer [1] built a theoretical model to simulate the relationship between the migration dynamics, remittances, real exchange rate and different sectors of the German economy. Contrary to popular belief that remittances eroded purchasing power of the economy and therefore harmed the host economy, they found that it actually 
benefited the German economy. The simulation concluded that an increase in remittances resulted in a corresponding increase in share of exports, an improvement in the trade balance and an increase in the country's GDP. The financial outflows resulted in the depreciation of the exchange rate, which in turn increased foreign demand and stimulated local production. This was observed to hold true in the part of the manufacturing sector that is export driven. However, remittances had an adverse effect in the services sector, where migrants' reallocation of funds from consumption to remittances decreased demand for service goods from their adopted country. These effects were amplified, depending on the migrants' plans for either temporary or permanent migration. The simulation study concluded that temporary migrants also sent almost twice as much in remittances as migrants planning on permanent stay.

Anti-migration proponents hold the negative impact migrants have on the host country's wages and how they take away jobs from locals to be a cornerstone of their standpoint. Supporting Baas and Melzer's [1] simulation studies, Olney, et al. [21] also concluded that remittances depressed wages of native workers and had negative effects on host economy's service industries. The study found that a $1 \%$ increase in remittances in Germany, depressed native workers' wages by $0.06 \%$. This study was also based on the German SocioEconomic Panel Study, which has robust data on remittances, wages and other economic data from 1984 - 2008. According to the World Bank [30], Germany is a net sender of remittances. Germany remitted over $\$ 21$ billion with the main beneficiaries being France $(\$ 1.9 \mathrm{bn})$, Italy $(\$ 1.8 \mathrm{bn})$ and Poland (\$1.4bn). Germany's estimated receipts of remittances were $\$ 13 \mathrm{bn}$. There is an estimated 10.7 million migrants in Germany, making it one of the top migrant destinations in the world. The recent migrant crisis in Germany has become a political hot bed, with The Cologne Institute for Economic Research announcing that shelter, welfare and integration will cost Germany $€ 22$ billion by the end of 2016 and $€ 27.6$ billion in 2017.

Several migration studies focusing on how migrants help in the economic development of not just their countries of origin, but also the host country, have honed in on the trade impact of these patterns, using a migration model derived from the original Newton's gravitational model, and used in economic modelling. Newton's formula for gravitational attraction between two masses is expressed as a function of the size of the two masses and the distance between them. The Newton gravity model has been widely used in migration studies, by taking the original equation and augmenting it with migration and economic variables. The model has been lauded for its empirical consistency and wide multi-disciplinary applicability. In migration studies, this implies that as migration between the two countries increases, the interaction (bilateral trade: imports and exports) for both countries should increase, as a function of the geographical proximity of the two destinations and the size of their economies (GDP). For the purposes of this study, this would imply that as migration increases between Zimbabwe and South Africa, the two countries should experience an increase in bilateral trade, benefiting both economies.

Gould [15] provides empirical evidence using the gravity model, that an increase in immigration by $10 \%$ into the USA, increased US exports to the source country by $4.7 \%$ and imports by $8.3 \%$. This pioneering study was based on a panel study of 47 US trade partners, with migration links.

Girma and $\mathrm{Yu}$ [13] provide pro-trade evidence of this link in a United Kingdom study based on two main levers: immigrants' effect on imports based on their preference for familiar products from home, and influence on exports based on their knowledge of the home country. Their study concluded that a $10 \%$ increase in immigrants from the nonCommonwealth countries had a long-term impact of a $5 \%$ increase in exports to those countries. Conversely same $10 \%$ increase in migrants from the Commonwealth countries had no impact on exports. They also found that a $10 \%$ increase in immigrants from the non-Commonwealth countries increased imports into the UK by $1 \%$, supporting the pro-trade effect. However, the same $10 \%$ increase in immigration from Commonwealth countries decreased imports from those countries by $1 \%$, but was statistically insignificant. They concluded that trade activity and migration linkage is powered by the 'newness' of trade information that the immigrants brought, which stimulated bilateral trade. According to their study, there is a higher likelihood for exports to the migrant's country of origin, especially those more remote from the host country.

The same gravity model has been used in other developed countries with similar results, with differing elasticities [6]. Paas [22], however, caution that as much as the gravity model helps to explain the trade patterns between countries, the model falls short in terms of estimating the absolute levels of trade flows.

Parsons [23] applied the gravity methodology to the European Union, to test the robustness of the model as well as to quantify the impact on the EU-15 bilateral trade flows. His study also predicted a positive correlation between immigration and trade flows between the host countries and countries of migrant origins. A $10 \%$ increase in migrants from Eastern Europe would increase exports to those countries by $1.2 \%$, and imports by $1.4 \%$. Parsons found that in computation of the gravity between the countries, the impact on their GDP was highly significant.

Faustino and Leitao [10] found a positive correlation between immigration and Portuguese bilateral trade. In their study, immigrants from Latin-partner countries had a stronger and more significant impact on Portuguese exports to their countries of origin, than those from non-Latin partner countries. The study found that immigration resulted in reduced transaction costs of trade, thus acting as a stimulus for trade, both exports and imports.

The Original Newton's "Law of Gravity"

A Dutch economist, Timbergen [28] was the first published proponent of the Newtonian gravity model's application in analysis of foreign trade. The original model, Newton's law of universal gravitation (shown below), states 
that the gravitational attraction between two objects is directly proportional to their individual masses, but inversely related to the square of the distance between the two.

$$
F_{i j}=G \frac{M_{i}^{\alpha} M_{j}^{\beta}}{\left(D_{i j}^{\theta}\right)^{2}}
$$

Where:

$F_{i j}=$ Attraction force between two body masses (Flow of trade)

$\mathrm{G}=$ Gravitational constant

$\mathrm{M}_{\mathrm{i}}, \mathrm{M}_{\mathrm{j}}=$ Masses of bodies $\mathrm{i}$ and $\mathrm{j}$ respectively (GDPs)

$\mathrm{D}_{\mathrm{ij}}^{\theta}=$ Distance between bodies $\mathrm{i}$ and $\mathrm{j}$ respectively (Distance)

Timbergen [28] substituted the mass of two countries with their respective GDPs, and used the distance between the countries in his model. The results, consistent with the original model propositions, were that GDP had a positive impact on the trade flows and distance proved to be inversely related to the trade flows. The study surmised that countries with larger economies and closer to each other tended to get more trade flows between the two of them. Other researchers followed suit in their studies on various economies and inserting augmented variables to explain trade flows $[17,20$, $26,27]$. The various model adaptations found success and favour in explaining trade flows and variances that other economic models could not explain.

Piperakis, et al. [26] also found supporting evidence in Greece consistent with the pro-trade model where exports showed a positive correlation, but there was not the same effect on imports. This was not consistent with Head and Ries' [16] study using Canada as a case study for its 136 partners, which postulated that a $10 \%$ increase in immigrants resulted in a $1 \%$ increase in exports and a corresponding 3\% increase in imports. The functional adoption of the model was as below:

$$
y_{i t}=\gamma_{0} M_{i t}+\beta_{0} G P_{i t}+\beta_{1} G D P C_{i t}+\beta_{1} D_{i s t}+D_{t}+\varepsilon_{i t}
$$

Where,

$y_{i t}=$ Greece's exports to/ imports from country $\mathrm{i}$ at time $\mathrm{t}$ $\mathrm{y}_{\mathrm{it}}=$ Immigrant stock originating from country $\mathrm{i}$ at time $\mathrm{t}$ $\mathrm{GDP}_{\text {it }}=$ Gross Domestic Product of country $\mathrm{i}$ at time $\mathrm{t}$ $\mathrm{GDPC}_{\mathrm{it}}=$ Gross Domestic Per Capita of country $\mathrm{i}$ at time $\mathrm{t}$

Dist $_{i t}=$ Great Circle distance from capital of country $i$ to Athens

$\mathrm{D}_{\mathrm{t}}=$ Time dummies for other micro economic variables that effect trade (used 10 year data)

Piperakis, et al. [26] ran the regression model on the 1981 to 1991 data, and their empirical findings were consistent with similar studies using this model. However, other country specific factors that they expected to have huge significance in the model proved insignificant. European countries' dominance in Greek trade, EU integration and language (French and English) predominance factors were all not significant in the study results. They also found that the impact of exports is less to poorer and further countries of migrants' origin, than the rest of the partner countries.

Vezina [26] provided evidence on pro-trade effects of migration based on Swiss immigration data and assessing two channels through which migrants impact trade. Based on the robust evidence, he concluded that a $10 \%$ increase in immigration could increase the number of exported goods to the migrants' home country by $1.5 \%$. He focused specifically on exports from Switzerland, with distinct categories of value versus volume of exports. He also concluded that migrants appeared to enhance the export of homogenous goods, reduced beachhead costs and provided information on their country of origin. This increased impact of migrant networks, with their country of origin, on overcoming informal barriers to trade is becoming more evident [27].

Rauch and Trindade [27] found that trade between countries with ethnic Chinese populations, experienced the smallest average increase in bilateral trade in differentiated products, estimated to be nearly $60 \%$, due to these strong ethnic connections.

Using the recently published data set released by the World Bank for 1980-2010, Ehrhart, Le Goff, Rocher and Singh [8] provided empirical evidence supporting migrations pro-trade impact in Africa. Sampling 52 African countries and their 195 trading partners in the world, they found that the impact was greater in African countries, especially for differentiated products and for ethnically and geographically distant countries from the destination country. Their study concluded that migrants assisted in addressing some of the major trade barriers in Africa, that include weak institutions, language barriers, mistrust and cultural barriers. Ehrhart, et al. [8] used the following key variables in their Gravity Model:

(1) Exports from country of origin

(2) Migrants in host country

(3) Geographical distance from of host country from countries of origin

A set of dummy variables was used measuring presence of common language and culture (15 distinct language families in Africa), common colonial past, a common border and other colonial ties, existence of bilateral social security agreements and portability of social benefits.

The application of the gravity model in explaining the macroeconomic determinants of remittances flows between countries has been largely hampered by the lack of bilateral flows of remittances data [18]. The main data sources for these on bilateral flows have been from IMF balance of payments publications, individual country reports that mostly do not provide the requisite breakdown of source and destinations. Other countries like Zimbabwe have limited data on remittances as a whole. However, Lueth and RuizArranz [18] applied the gravity model to explain remittances impact and macroeconomic variables, using a dataset from 11 countries over a period 1980-2004, with significant success. The dataset accounted for about 200 pairings yielding nearly 1,650 data points for observation. The model employed the common variables of GDP, distance and common language between the countries, which explained over $50 \%$ of the variation in remittance flows.

The study concluded that the remittances motives were mixed, with altruism motivation most likely less significant 
that commonly believed. They also found a positive correlation in the ratio of dependency and the size of remittances, suggesting that the need to support families back home was a significant motivator for remittances. The inflation rate of the home country was also found to influence remittances flows, as a compensatory factor for any loss in purchasing power, for dependencies in country of origin. Natural disasters or other catastrophes did not seem to significantly impact remittance flows, compared to the positive correlation observed between remittances and home country economic environment. The better the economic environment and the more vibrant the business cycle was in the home country, the greater the remittances observed. This evidence pointed to the investment motive as a key driver. This was supported by further evidence that when the political climate worsens and the country's currency depreciates, remittances are diminished. The study put out a cautionary statement that remittances should definitely be encouraged but not be revered as a panacea.

Freund and Spatafora [12] posited that remittances through informal channels tend to be underestimated, citing that they are as significant as between $35 \%$ and $250 \%$ of recorded remittances. AITE (2006) went on to add that actual remittances were understated by close to $250 \%$. Current estimations for most informal remittances channels flows are done using household survey data, on the sending as well as on the recipient end. There is limited empirical methodology work on these estimates globally [12].

\section{Results and Discussion}

The researcher first analysed the gravity model for trade for adaptation, an extension of the model provided in
Krugman and Obsfelt [17]. In addition to the economy size of the countries (the GDP) and the distance between their capital cities, we took into consideration the immigration variable. The researcher assumed that the proximity (or border) between countries is a major factor that facilitates immigration. The model is given by:

$$
\begin{gathered}
\ln \left(\mathrm{R}_{\mathrm{jt}}\right)=\alpha_{0}+\alpha_{1} \ln \left(\mathrm{Y}_{\mathrm{t}}\right)+\alpha_{2} \ln \left(\mathrm{Y}_{\mathrm{jt}}\right)+\alpha_{3} \ln \left(\mathrm{D}_{\mathrm{j}}\right)+ \\
\alpha_{4} \mathrm{BD}_{\mathrm{j}}+\mathrm{e}_{\mathrm{jt}},(*)
\end{gathered}
$$

where

" $t$ " is the observation period (2010-2015)

" $\mathrm{R}_{\mathrm{jt}}$ " is the remittance flow from South Africa to the receiving county $\mathrm{j}$ in year $\mathrm{t}$

" $Y_{t}$ " is the GDP of South Africa in year $t$

" $Y_{j t}$ " is the GDP of the receiving country $\mathrm{j}$ in year $\mathrm{t}$

" $\mathrm{D}_{\mathrm{j}}$ " is the distance between South Africa and the receiving country $\mathrm{j}$

" $\mathrm{BD}_{\mathrm{j}}$ " is the immigration dummy variable

" $\mathrm{e}_{\mathrm{jt}}$ " is a constant standing for an error term.

The study noted that the subscript " $j$ " represents the receiving country. In this analysis, the researcher considered " $\mathrm{j}=1$ for Botswana", " $\mathrm{j}=2$ for Lesotho", " $\mathrm{j}=3$ for Malawi", " $\mathrm{j}=4$ for Mozambique" and " $\mathrm{j}=5$ for Australia".

The distance is measured between Johannesburg city and the capital city of the receiving country. Distance can affect the transportation cost during the trade and the remittance.

The researcher set a value of 1 to the dummy variable $B D_{j}$ if the receiving country $\mathrm{j}$ shares a geographical border with South Africa, and a value of 2 otherwise.

The descriptive statistics of the above independent variables $\left(Y_{j t}, Y_{j}, D_{j}, B D_{j}\right)$ and dependent variable $\left(R_{j t}\right)$ are presented in Table 1.

Table 1. Analysis of Remittances as the dependent variable.

\begin{tabular}{lllllll}
\hline Variables & Unit & Obs. & Mean & Std. Dev. & Min & Max \\
\hline $\mathrm{R}_{\mathrm{it}}$ & Million & 30 & 119.01 & 178.7 & 1.84 & 549.17 \\
$\mathrm{Y}_{\mathrm{t}}$ & Million & 30 & 369676.67 & 33841.01 & 312800 & 416600 \\
$\mathrm{Y}_{\mathrm{it}}$ & Million & 30 & 288537 & 571204.62 & 2280 & 1563900 \\
$\mathrm{D}_{\mathrm{i}}$ & Km & 30 & 2849.3 & 4215.9 & 360.5 & 11060 \\
$\mathrm{BD}_{\mathrm{j}}$ & 1: sharing a border & 30 & 1.40 & 0.498 & 1 & 2 \\
\hline
\end{tabular}

To assess the influence of the economic size of receiving countries, the distance and the immigration factor on their remittance in flow $\mathrm{R}_{\mathrm{jt}}$, we performed a multi-regression test using the equation $(*)$. The estimation results are presented in Table 2 .

Research question 1: Do inflow remittances have an impact on the GDPs of the receiving countries?

\begin{tabular}{|c|c|c|c|c|c|c|}
\hline & & \multirow{3}{*}{ Statistic } & \multicolumn{4}{|c|}{ Bootstrap $^{a}$} \\
\hline & & & \multirow{2}{*}{ Bias } & \multirow{2}{*}{ Std. Error } & \multicolumn{2}{|c|}{ 95\% Confidence Interval } \\
\hline & & & & & Lower & Upper \\
\hline \multirow{3}{*}{ GDP in $\ln$} & Mean & 3.0780 & -.0068 & .3920 & 2.3355 & 3.8709 \\
\hline & Std. Deviation & 2.21567 & -.05315 & .28383 & 1.48327 & 2.61281 \\
\hline & $\mathrm{N}$ & 30 & 0 & 0 & 30 & 30 \\
\hline \multirow[b]{2}{*}{ Remittance in ln } & Mean & 3.60172 & .00395 & .29782 & 3.02850 & 4.18232 \\
\hline & Std. Deviation & 1.669210 & -.023143 & .172354 & 1.273485 & 1.956503 \\
\hline
\end{tabular}

Table 2. Descriptive Statistics.

a. Unless otherwise noted, bootstrap results are based on 1000 bootstrap samples 
Table 3. Model Summary ${ }^{b}$.

\begin{tabular}{llll}
\hline Model & R & R-Square & Adjusted R-Square \\
\hline 1 & $.426 \mathrm{a}$ & .181 & .152 \\
\hline
\end{tabular}

a. Predictors: (Constant), Remittance in ln

b. Dependent Variable: GDP in $\ln$

Table 2 indicates the amount of variance explained by the model as specified in the research question 1 . Since we are dealing with a small sample size, it is appropriate using the adjusted R-square value. According to the result, remittance flow in the receiving countries accounts for $15.2 \%$ of the GDP variance of the receiving countries. Meaning $15.2 \%$ of the variations in terms of GDP of the receiving countries are caused by the remittance flow variation.

Table 4. ANOVA .

\begin{tabular}{lllllll}
\hline Model & & Sum of Squares & Df & Mean Square & F & Sig. \\
\hline \multirow{3}{*}{1} & Regression & 25.823 & 1 & 25.823 & 6.204 \\
& Residual & 116.544 & 28 & 4.162 & \\
& Total & 142.367 & 29 & & \\
\hline
\end{tabular}

a. Dependent Variable: GDP in $\ln$

b. Predictors: (Constant), Remittance in $\ln$

Table 4 indicates that the model specified by the research question 1 is valid as its F-value (6.204) is significant ( $\mathrm{p}=.019$ $<.05)$. This significance simply means that the proposed model statistically makes sense.

Table 5. Coefficients ${ }^{a}$.

\begin{tabular}{llllll}
\hline \multirow{2}{*}{ Model } & & \multicolumn{2}{l}{ Unstandardised Coefficients } & \multicolumn{2}{l}{ Standardised Coefficients } \\
\cline { 3 - 5 } & B & Std. Error & Beta & \\
\hline \multirow{2}{*}{1} & (Constant) & 5.114 & .898 & & 5.693 \\
& Remittance in $\ln$ & -.565 & .227 & -.426 & -000 \\
\hline
\end{tabular}

a. Dependent Variable: GDP in ln

A linear regression analysis was conducted to test whether inflow remittances have an impact on the GDPs of the receiving countries.

According to the results (Table 5), there is an overall negative and significant relationship between the inflow of remittances and the GDPs of the receiving countries as the Beta value is negative $(-.426)$ and the p-value $(.019<.05)$ is significant. The means that any increase of one standard deviation (1.66-Table 1) of remittance will correspond to a GDP lower of $42.6 \%$ of the GDP's standard deviation (2.2156 - Table 1). In other words, countries which have high remittances inflow still report low GDPs; which is the case of Zimbabwe as an example. It also would mean that a growth in remittances inflow would not translate into a growth in GDPs in most of the receiving countries. This is probably due to the fact that most of the remittances are sent for consumption purposes. For example, $65.45 \%$ remittances sent to Zimbabwe are sent for conspicuous consumption and only $5.81 \%$ are sent for investment. Apparently, the percentage sent for investment in the receiving country is usually too small to boost the GDPs of countries with low GDPs.

Table 6. Bootstrap for Coefficients.

\begin{tabular}{|c|c|c|c|c|c|c|c|}
\hline \multirow{3}{*}{\multicolumn{2}{|c|}{ Model }} & \multirow{3}{*}{ B } & \multicolumn{5}{|c|}{ Bootstrapa } \\
\hline & & & \multirow{2}{*}{ Bias } & \multirow{2}{*}{ Std. Error } & \multirow{2}{*}{ Sig. (2-tailed) } & \multicolumn{2}{|c|}{ 95\% Confidence Interval } \\
\hline & & & & & & Lower & Upper \\
\hline \multirow{2}{*}{1} & (Constant) & 5.114 & .098 & 1.218 & .003 & 3.276 & 8.103 \\
\hline & Remittance in $\ln$ & -.565 & -.018 & .250 & .048 & -1.195 & -.198 \\
\hline
\end{tabular}

a. Unless otherwise noted, bootstrap results are based on 1000 bootstrap samples

Bootstrapping is a resampling technique performed by statistical Softwares such as SPSS, Amos, etc. to improve the accuracy of the results obtained on small samples. A bootstrap of 1000 samples (Table 5) was therefore performed to minimise the effect size of our small sample (30 units). The bootstrap results confirm that there is a negative relationship between remittances inflow and the GDPs of the receiving countries as the "B value" is negative (-565) and the p-value of the relationship is still significant $(.048<.05)$.
In conclusion, there are at least $95 \%$ of chances that the results obtained in the regression test are accurate.

Testing the Impact of Remittances on the South African GDP

Research Question 2: Do outflow remittances have an impact on the GDPs of South Africa as the sending country? 
Table 7. Descriptive Statistics.

\begin{tabular}{|c|c|c|c|c|c|c|}
\hline & & \multirow{3}{*}{ Statistic } & \multicolumn{4}{|c|}{ Bootstrap $^{a}$} \\
\hline & & & \multirow{2}{*}{ Bias } & \multirow{2}{*}{ Std. Error } & \multicolumn{2}{|c|}{ 95\% Confidence Interval } \\
\hline & & & & & Lower & Upper \\
\hline \multirow{3}{*}{ GDP SA_ 2 in $\ln$} & Mean & 12.8162 & .0002 & .0165 & 12.7839 & 12.8498 \\
\hline & Std. Deviation & .09347 & -.00224 & .00996 & .06975 & .10894 \\
\hline & $\mathrm{N}$ & 30 & 0 & 0 & 30 & 30 \\
\hline \multirow[b]{2}{*}{ Remittance in ln } & Mean & 3.60172 & -.00931 & .30615 & 3.02211 & 4.25316 \\
\hline & Std. Deviation & 1.669210 & -.041263 & .180528 & 1.266643 & 1.959710 \\
\hline
\end{tabular}

a. Unless otherwise noted, bootstrap results are based on 1000 bootstrap samples

Table 8. Model Summary ${ }^{b}$.

\begin{tabular}{lllll}
\hline Model & R & R-Square & Adjusted R-Square & Std. Error of the Estimate \\
\hline 1 & $.108 \mathrm{a}$ & .012 & -.024 & .09457 \\
\hline
\end{tabular}

a. Predictors: (Constant), Remittance in $\ln$

b. Dependent Variable: GDP SA_ 2 in $\ln$

Table 8 indicates the amount of variance explained by the model as specified in the research question 2. According to the result, the variation of the remittance outflow from South Africa accounts for only $2.4 \%$ of the variance of the South African GDP. Meaning only $2.4 \%$ of the changes of the South African GDPs are the result of the variation of the remittance outflow.

Table 9. ANOVA

\begin{tabular}{lllllll}
\hline Model & & Sum of Squares & Df & Mean Square & F & Sig. \\
\hline \multirow{3}{*}{1} & Regression & .003 & 1 & .003 & .328 \\
& Residual & .250 & 28 & .009 & \\
& Total & .253 & 29 & & \\
\hline
\end{tabular}

a. Dependent Variable: GDP SA_2 in ln

b. Predictors: (Constant), Remittance in $\ln$

Table 9 indicates that the model specified by the research question 2 is not significant as its F-value (.328) is not significant $(\mathrm{p}=.571>.05)$. This non-significance implies that relationship between the predictor (remittance outflow) and the dependent variable (SA GDP) is likely to be non-significant.

\section{Analytical Conclusion of Model}

Table 10 below summarises the conclusions the researcher arrived at after conducting the above mode analysis, albeit with the limited data sets.

Table 10. Summary of conclusions.

\begin{tabular}{|c|c|c|}
\hline Analysis & Observation & Conclusion \\
\hline $\begin{array}{l}\text { Effect of economic size of } \\
\text { recipient countries on } \\
\text { remittances flow }\end{array}$ & $\begin{array}{l}15.2 \% \text { of the variations in terms of GDPs of recipient countries } \\
\text { are caused by remittance flow variations } \\
\text { A one standard deviation increase of remittances corresponded to } \\
\text { a standard deviation of GDP lowering by } 42.6 \%\end{array}$ & $\begin{array}{l}\text { Remittances have a significant impact on recipient } \\
\text { economies } \\
\text { Negative correlation between GDP and remittances } \\
\text { inflows of the recipient countries observed }\end{array}$ \\
\hline $\begin{array}{l}\text { Bootstrap Analysis to boost } \\
\text { sample size }\end{array}$ & $\begin{array}{l}\text { B value was negative }(-565) \text {, and the P-value of the relationship } \\
\text { was significant }(0.048)\end{array}$ & $\begin{array}{l}\text { Negative relationship between remittances inflow and } \\
\text { GDPs }\end{array}$ \\
\hline $\begin{array}{l}\text { Impact of remittances outflow } \\
\text { on the SA economy }\end{array}$ & $\begin{array}{l}\text { Variation of the remittances outflow from SA accounts for } 2.4 \% \text { of } \\
\text { the variance on GDP }\end{array}$ & $\begin{array}{l}\text { Outflow of remittances have no significant impact on } \\
\text { the GDP of SA }\end{array}$ \\
\hline $\begin{array}{l}\text { Influence of distance on } \\
\text { remittances flow }\end{array}$ & $\begin{array}{l}\text { An increase of } 1 \% \text { in distance from SA to the receiving countries } \\
\text { decreases remittances by } 0,89 \%\end{array}$ & $\begin{array}{l}\text { Distance from the sending country has a significant } \\
\text { and negative impact on remittances inflow }\end{array}$ \\
\hline $\begin{array}{l}\text { Reverse GDP influence on } \\
\text { remittances inflow }\end{array}$ & $\begin{array}{l}1 \% \text { decrease in GDP of recipient country, increases remittances } \\
\text { inflow by } 1.53 \%\end{array}$ & $\begin{array}{l}\text { Economic impairment of receiving countries increase } \\
\text { their dependence on SA remittances inflow }\end{array}$ \\
\hline
\end{tabular}

\section{Limitations of the Study}

The following are the limitations of this study:

(1) This study examined the impact of remittances on the economic development on both the sending and the receiving economies, through three seemingly dichotomous analytical lenses. The empirical conclusions drawn from the study are both profound and significant for future research in this field of study, 
remittances and economic development, but these should be regarded with caution. In the wider international research context, the results and findings of this study may vary given the various exogenous and endogenous variables inherent in the remittances corridor researched. The findings should be incorporated into future similar research initiatives as conceptual models, where the contexts are different. The study drew on wider pool of literature material, but focused the research on the South Africa and Zimbabwe remittances corridor; hence, generalisation of the findings would require verification first. Herewith are the other important limitations acknowledged in this study:

(2) The researcher attempted to use the adaptation of the Newtonian Gravity model, now commonly used in bilateral trade studies, to investigate remittances against economic development impact with limited success. Even though this was a complementary study, to contrast and augment the two main research tools, the lack of bilateral data for the two identified countries was limiting. Researcher then chose a few countries as proxies for the main corridor, but only six data points could be identified for the research. These added a view point to the research, but the results could not be fully conclusive, even after applying the bootstrap methodology to increase the data points.

(3) The researcher performed a simple regression analysis of total remittances of SA and Zimbabwe against GDPs. Even though the results confirmed the proxy countries' findings, on their own they are not conclusive. Bilateral remittances volumes would have been the correct data sets to provide independent conclusive findings.

While acknowledging the above limitations, the researcher also noted that the time this study was conducted could have been in a poor economic cycle for Zimbabwe, which could produce different results in a different cycle. However, the study provides solid groundwork for future studies in this area, and adds depth to the current dearth in academic research in this field and in the very significant remittance corridor.

\section{Conclusion}

This study undertaken by the researchers involved an empirical investigation into the impact of remittances on the recipient and receiving economies, with a focus on the Zimbabwe and South remittances corridor. Through the adaptation of the original Newton's Gravity model, the following conclusion/s could have been reached: a positive impact of remittances and a negative impact or non-conclusive nature of impact of remittances, with sender and receiver permutations, or non-applicability of the model to remittances flow. The first conclusion was that international remittances have a significant impact on recipient economies, in particular with Zimbabwe, the impact was an inverse relationship. On the other hand, remittances out-flows of the sending country had very little direct impact on its economy, in this study South Africa. The differentials in the size of the economies was also a big factor in the impact sensitivities analysis. As in the Newton model, the distance between the sending and recipient countries was a significant variable in the velocity of the remittances flows. The other major finding was that the greater the economic impairment of the recipient country, the higher the flow of remittances got. This last finding supported the role of remittances as compensatory income during economic hardship for recipient countries, thus not directly contributing to economic growth. The researchers acknowledge some limitations to the study, such as timing of the study when the focal recipient country, Zimbabwe, was going through an economic down turn. However, the empirical study provides for solid ground work for future studies and will assist policy makers and other key stakeholders in policy formulation and adaptations to better understand remittances flows dynamics and key drivers, to leverage for economic development purposes.

\section{References}

[1] Baas, T. and Melzer, S. M. 2012. The macroeconomic impact of remittances: A sending country perspective. Journal of International Economics. Norface Migration Discussion Paper No. 2012-21.

[2] Barajas, A., Chami, R., Fullenkamp, C., Gapen, M. \& Montiel, P. (2009). Do workers remittances promote economic growth? IMF Working Paper, Middle Eastern and Central Asian Department.

[3] Bracking, S. and Sachikonye, L. 2006. Remittances, poverty reduction and the informalisation of household wellbeing in Zimbabwe. Oxford: GPRG.

[4] Crush, J. and D. Tevera (2010). "Exiting Zimbabwe." In Zimbabwe's exodus: Crisis, migration, survival, edited by J. Crush and D. Tevera. Page 51. Ottawa: International Development Research Centre.

[5] De Haas, H. 2005. International migration, remittances and development: Myths and facts. Third World Quarterly. 26(8): 1269-1284.

[6] Desai, M. A., Kapur, D. \& McHale, J. 2001. Sharing the spoils: Taxing international human capital flows. Weekly Political Economy Discussion Paper, Harvard University.

[7] Dustmann, C. and Mestres, J. 2010. Remittances and temporary migration. Journal of Development Economics, 92: 62-70.

[8] Ehrhart, H., Le Goff, M., Rocher, E. \& Singh, R. J. 2014. Does migration foster exports: Evidence from Africa. Policy Research Working Paper 6739, New York: Poverty Reduction and Economic Management Unit, The World Bank.

[9] Eurotrade, 2012, Zimbabwe, EU Bilateral Trade and Trade with the World, 5-13 July, http://trade.ec.europa.eu/doclib/docs/2011/january/tradoc_147 429.pdf.

[10] Faustino, C. H. and Leitao, N. C. 2008. Using the gravity equation to explain the Portuguese immigration-trade link. WP12/2008/DE/SOCIUS. Lisbon: School of Economics and Management, Technical University of Lisbon. 
[11] Finmark Trust, 2015. Remittances from South Africa to SADC. Geoff Orpen, $26^{\text {th }}$ March 2015.

[12] Freund, C. and Spatafora, N. 2005. Remittances: Transaction Costs, determinants and informal flows. World Bank Policy Research Working Paper 3704. Washington, D. C.: World Bank.

[13] Girma, F. and Yu, G. 2002. The link between immigration and trade: Evidence from the United Kingdom, Weltwirtschaftliches Archiv, 138 (1).

[14] Giuliano, P. and Ruiz-Arranz, M. (2006). 'Remittances, Financial Development and Growth'. IZA Discussion Papers, No. 2160. http://hdl.handle.net/10419/34035.

[15] Gould, D. M. 1994. Immigrant links to the home country: Empirical implications for U.S. bilateral trade flows. In The Review of Economics and Statistics, MIT Press.

[16] Head, K. and Ries, J. 1998. Immigration and trade creation: Econometric evidence from Canada. Canadian Journal of Economics, 31 (1): 47-62.

[17] Krugman, P. R. \& Obstfeld, M. 2005. International economics: Theory and practice. $\left(7^{\text {th }}\right.$ ed.). Boston: Addison-Wesley.

[18] Lueth, E. and Ruiz-Arranz, M. 2006. A gravity model of workers' remittances. IMF Working Paper. Asia and Pacific Department. WP/06/290.

[19] Maphosa, F. 2005. The impact of remittances from Zimbabweans working in South Africa on rural livelihoods in southern districts of Zimbabwe. Forced Migration Working Paper Series \#14.

[20] Martínez-Zarzoso, I. \& Nowak-Lehmann, F. D. 2004. Economic and Geographical Distance: Explaining Mercosur Sectoral Exports to the EU. Open Economies Review (2004) 15: 291

[21] Olney, W. W. 2014. Remittances and the wage impact of immigration. Journal of Human Resources, 50 (3): 694-727 in international trade: Using a gravity approach for exploring bilateral trade flows. The $42^{\text {nd }}$ Congress of the European Regional Science Association, August 2002, Dortmund, Germany.

[22] Paas, T. 2002. European integration and EU Eastward enlargement process in international trade: Using a gravity approach for exploring bilateral trade flows. The $42^{\text {nd }}$ Congress of the European Regional Science Association, August 2002, Dortmund, Germany.

[23] Parsons, C. 2005. Quantifying the trade - migration nexus of the enlarged EU: A comedy of errors or much ado about nothing? Sussex Migration Working Paper no. 27, Sussex Centre for Migration Research.

[24] Partridge, A. 2013. Africa-South Africa trading relationship, [Online]. Available from: http://www.tralac.org/files/2013/10/Africa-South-Africatrading-relationship_Synopsis.pdf [Accessed 27 April 2017].

[25] Paton, B. 1995. Labour export policy in the development of Southern Africa. Harare. University of Zimbabwe.

[26] Piperakis, S. A., Milner, C. \& Wright, P. W. 2003. Immigration, trade costs and trade: Gravity evidence of Greece. Journal of Economic Integration 18 (4).

[27] Rauch, J. and Trindade, V. 2002. Ethnic Chinese networks in international trade. The Review of Economics and Statistics, 84 (1).

[28] Tinbergen, Jan. Shaping the World Economy: Suggestions for an International Economic Policy. New York: The Twentieth Century Fund, 1962.

[29] Vezina, P. 2011. How migrant networks facilitate trade: Evidence from Swiss Exports, London: OxCarre and Department of Economics, University of Oxford.

[30] World Bank 2013. Remittances prices worldwide, Q3 [Online]. Available from: http://go.worldbank.org/7RKUKJF3Q0 [Accessed 14 May 2015]. 